\title{
Open-label study comparing the efficacy and tolerability of aripiprazole and haloperidol in the treatment of pediatric tic disorders
}

\author{
Hanik K. Yoo $\cdot$ Joong-Sun Lee $\cdot$ Kyoung-Won Paik • \\ Soon-Ho Choi $\cdot$ Sujung J. Yoon · Jieun E. Kim • \\ Jin Pyo Hong
}

Received: 29 March 2010/Accepted: 15 December 2010/Published online: 28 December 2010

(C) The Author(s) 2010. This article is published with open access at Springerlink.com

\begin{abstract}
Due to its unique pharmacodynamic properties of dopamine partial agonist activity, and its association with few and mild side effects, aripiprazole is a candidate atypical antipsychotic for patients with tic disorders. This open-label study compared the efficacy and tolerability of aripiprazole with haloperidol, a typical antipsychotic widely used to treat patients with tic disorders. Forty-eight children and adolescents with tic disorders were recruited from the outpatient clinic at South Korea and treated with aripiprazole (initial dose, $5.0 \mathrm{mg} / \mathrm{d}$; maximum dose $20 \mathrm{mg} / \mathrm{d}$ ) or haloperidol (initial dose, $0.75 \mathrm{mg} / \mathrm{d}$; maximum dose, $4.5 \mathrm{mg} / \mathrm{d}$ ) for 8 weeks. Treatment efficacy was measured using the yale global tic severity scale (YGTSS), and tolerability was measured using the extrapyramidal symptom rating scale (ESRS) and an adverse effects checklist. Total tic scores as measured by the YGTSS decreased over time in both groups $(p<0.001)$ without any significant differences between groups. ESRS scores were significantly higher in the haloperidol group
\end{abstract}

H. K. Yoo ( $\varangle)$ · J.-S. Lee · S.-H. Choi · J. P. Hong

Department of Psychiatry, University of Ulsan College

of Medicine, Asan Medical Center, 388-1 Pungnap-2 dong,

Songpa-gu, Seoul 138-736, South Korea

e-mail: hiyoo@amc.seoul.kr

K.-W. Paik

Department of Psychiatry, Hanyang University Medical Center, Seoul, South Korea

\section{S. J. Yoon}

Department of Psychiatry, Catholic University Medical College,

St. Paul Hospital, Seoul, South Korea

\section{J. E. Kim}

Department of Psychiatry, Seoul National University College of Medicine, Seoul National University Hospital,

Seoul, South Korea during the 4 weeks after commencement of medication $(p<0.05)$. These results indicate that aripiprazole may be a promising drug in the treatment of children and adolescents with tic disorders. Further controlled studies are needed to determine the efficacy and tolerability of aripiprazole in these patients.

Keywords Aripiprazole - Tic disorders - Tourette disorder · Children · Adolescents · Haloperidol

\section{Introduction}

Typical antipsychotics such as haloperidol and pimozide have been prescribed to control tic symptoms as first-line agent [1]. More recently, clinical experience with atypical neuroleptics have increased owing to the efficacy and the more tolerable adverse effects relative to some classical antipsychotics [1-11]. Some drugs such as risperidone [7, 12], quetiapine [13], and olanzapine [4, 10, 11], however, may cause unwanted metabolic side effects, which may worsen patient quality of life as well as general medical health status.

Aripiprazole is another candidate atypical antipsychotic agent for patients with tic disorders. This drug has a lower risk of metabolic side effects than other atypical neuroleptics. In addition, aripiprazole has a unique pharmacodynamic property, namely dopamine partial agonist activity [14]. Because abnormalities in the brain dopamine system may be closely related to the pathology of tic disorders [15], we hypothesized that aripiprazole may have therapeutic effects on tic manifestations. Several clinical trials, including our previous studies, have revealed that aripiprazole may be successful in treating patients with tic disorders, due to its high efficacy and tolerability [16-24]. 
No study to date, however, has compared the efficacy and tolerability of aripiprazole and typical antipsychotics in these patients. We therefore compared the efficacy and tolerability of aripprazole with haloperidol, a typical antipsychotic agent widely used to treat children and adolescents with tic disorders.

\section{Methods}

\section{Participant characteristics}

Forty-eight children and adolescents with tic disorders (33 males, 15 females; mean $\pm \mathrm{SD}$ age $=10.3 \pm 3.5$ years; range, 6-15 years) were recruited at an outpatient clinic at a general hospital in Seoul, South Korea, from August 2005 to March 2007. Before determining eligibility, we obtained informed consent and assent from both the study subject and the child's primary caregiver. The study protocol was approved by our local Institutional Review Board.

Patients were deemed eligible if they had DSM-IV diagnosis of tic disorders, as described in the Korean version of the Kiddie-Schedule for Affective Disorders and Schizophrenia-Present and Lifetime Version (KSADS-PL [25]) and Total Tic scores $\geq 22$ on the Korean version of the yale global tic severity scale (YGTSS $[26,27]$ ), corresponding to at least moderate tic severity. Each patient was subsequently examined by a board-certified child psychiatrist.

Exclusion criteria included current mood disorders, psychotic symptoms, and anxiety disorders, except for obsessive-compulsive disorder, the most common comorbid anxiety disorder in tic patients. Subjects with an IQ $\leq 70$ on the Korean version of the Wechsler Intelligence Scale for Children-Revised (WISC-R [28]) were also excluded, as were patients with previous or current seizure episodes, electroencephalogram (EEG) abnormalities, and those who had used aripiprazole previously. Subjects who had taken psychotropic medications must have been drugfree for at least 2 weeks before study entry and had to be devoid of any significant medical problems.

\section{Study design}

This was an open, non-randomized, parallel-group clinical trial. All subjects were evaluated at baseline by routine laboratory tests, electrocardiogram (ECG), resting pulse rate and blood pressure while sitting, height and weight measurement, medical history, and physical and neurological examinations. Choice of treatment was based on patient's preference. Patients in the aripiprazole group started at a dose of $5.0 \mathrm{mg} / \mathrm{d}$, which was increased in
$5.0-10.0 \mathrm{mg} / \mathrm{d}$ increments every 2 weeks as tolerated [23, 24]. Doses were reduced in $2.5-5.0 \mathrm{mg} / \mathrm{d}$ steps when intolerable side effects emerged. The maximum allowable dose was $20 \mathrm{mg} / \mathrm{d}$ and patients were treated for 8 weeks. Patients in the haloperidol group were started at a dose of $0.75 \mathrm{mg} / \mathrm{d}$ and increased in $1.5-3.0 \mathrm{mg} / \mathrm{day}$ increments every 2 weeks to a maximum tolerated dose of $4.5 \mathrm{mg} / \mathrm{d}$ [29]. Psychotropic drugs to control comorbid psychiatric symptoms were not prescribed during the study period. Patients were assessed every other week, with the final assessment 8 weeks after the start of study medications.

\section{Measurements}

The YGTSS is a semi-structured clinical interview designed to assess current tic severity; this scale yields three summary scores; total motor (0-25), total phonic (0-25), and total tic (sum of motor and phonic) scores. The YGTTS also contains an impairment scale (0-50), which evaluates the global level of functional impairment arising from tics [27]. Because this study was designed to compare efficacy in reducing tic symptoms, the primary outcome measure was total tic score. The YGTSS was administered to each subject at each visit.

Secondary outcome measures included the Clinical Global Impressions-Improvement scale (CGI-I [30]), and the CGI-Severity of Illness scale (CGI-S [31]). Scores of 1 (very much improved) or 2 (much improved) in the CGI-I were regarded as positive responses. Both of these tests were administered at every visit.

Adverse effects associated with these drugs were assessed using an in-house adverse effect checklist, which included the most commonly encountered side effects of aripiprazole and haloperidol, as well as general questions on health issues, current illnesses or injuries, and concomitant medical treatments. The Extrapyramidal Symptom (EPS) Rating Scale (ESRS) was also used to rate the severity of Parkinsonism, akathisia, dystonia, and dyskinesia [32]. We measured height and weight at every visit. At the study endpoint, physical and neurological examinations, laboratory tests, and ECG assessments were repeated.

All tests were admitted by a single psychiatrist, who was blinded to dose changes but not to the drug of choice.

\section{Statistical analyses}

We used intent-to-treat analyses, based on patients assessed at least once after baseline. Multiple linear regression and generalized estimation equation (GEE) regression modeling were used to identify medication efficacy and the significance of changes in ESRS scores. Age, gender, duration of illness, and baseline scores of each outcome were covariates for each analysis. Fisher's exact test and the 
Mann-Whitney $U$ test were used as appropriate for between-group comparisons. All analyses were two-sided, with statistical significance defined at an $\alpha$ level of 0.05 .

\section{Results}

Participant characteristics

Of the 48 children and adolescents with tic disorders, 31 were prescribed aripiprazole and 17 were prescribed haloperidol. Twenty-six patients $(54.1 \%)$ had Tourette's disorder and $11(21.9 \%)$ had chronic motor and vocal tic disorders. Eighteen participants $(37.5 \%)$ had other comorbid psychiatric disorders, the most common being attention-deficit hyperactivity disorder $(31.3 \%)$. The mean duration of illness was $3.0 \pm 2.7$ years and 18 subjects $(37.5 \%)$ had a history of previous medication to control tic symptoms.

Although gender ratio, total IQ, type of tic disorders, comorbid conditions, duration of illness, and study medications did not differ between the two groups, the mean age was significantly higher in the aripiprazole than in the haloperidol group $(11.2 \pm 3.5$ years vs. $8.6 \pm 2.9$ years; $Z=2.68, p<0.01)$. The mean dose and duration of aripiprazole were $10.6 \pm 5.2 \mathrm{mg} / \mathrm{d}$ and $51.7 \pm 12.6 \mathrm{~d}$, respectively, whereas the mean dose and duration of haloperidol were $1.9 \pm 1.1 \mathrm{mg} / \mathrm{d}$ and $46.3 \pm 15.8 \mathrm{~d}$, respectively (Table 1).

Efficacy of aripiprazole and haloperidol: yale global tic severity scale

At baseline and at each follow-up visit, there were no significant between-group differences in tic scores, indicating that these two drugs were similarly efficacious in reducing tic symptoms (Table 2). After 8 weeks of treatment, $54.3 \%$ of the aripiprazole and $63.4 \%$ of the haloperidol group showed reductions in total tic scores. Total tic score decreased over time in both groups $(Z=$ $-9.60, p<0.001$ ) (Table 2). This reduction was particularly marked at the first follow-up visit (week 2) in both groups $(p<0.001)$ and was sustained throughout the study period (Fig. 1a). There were no significant between-group effects or interactions.

At baseline, the mean motor tic score was higher in the haloperidol than in the aripiprazole group $(20.5 \pm 3.1$ vs. $17.5 \pm 5.3 ; Z=-1.87, p=0.06)$, but the difference did not reach statistical significance. Aripiprazole reduced motor tic scores $54.3 \%$ and phonic tic scores $50.0 \%$, whereas haloperidol reduced these scores by 58.5 and $66.2 \%$, respectively. Motor $(Z=-8.29, p<0.001)$ and phonic $(Z=-5.59, p<0.001)$ tic scores decreased over time in both groups (Table 2; Fig. 1b, c), but there were no significant between-group effects or interaction terms.

Efficacy of aripiprazole and haloperidol: clinical global impression

The CGI-S scores of both groups decreased over time $(Z=-8.83, p<0.001)$ without group or interaction effects. Twenty-two children and adolescents $(71.0 \%)$ in the aripiprazole group and ten $(58.8 \%)$ in the haloperidol group were "much improved" or "very much improved" on the CGI-I measurement after 8 weeks of medication.

\section{Dropout rate}

Although 25 children and adolescents in the aripiprazole group $(80.6 \%)$ experienced one or more unwanted side effects, only five (16.1\%) patients in this group discontinued
Table 1 Demographic and clinical characteristics of the 48 children and adolescents with tic disorders

${ }^{\mathrm{a}} p<0.01$ by the MannWhitney $U$ Test $I Q$ intelligence quotient

\begin{tabular}{|c|c|c|}
\hline & $\begin{array}{l}\text { Aripiprazole group } \\
(n=31)\end{array}$ & $\begin{array}{l}\text { Haloperidol group } \\
(n=17)\end{array}$ \\
\hline Male, $n(\%)$ & $22(71.0)$ & $11(64.7)$ \\
\hline Age mean ${ }^{\mathrm{a}}(\mathrm{SD})$, years & 11.2 (3.5) (range: 6-18) & 8.6 (2.9) (range: 6-16) \\
\hline Total IQ & $108.2 \pm 12.4$ & $105.5 \pm 9.1$ \\
\hline \multicolumn{3}{|l|}{ Type of tic disorders } \\
\hline Tourette's disorder, $n(\%)$ & $19(61.3)$ & $7(41.2)$ \\
\hline Chronic motor and vocal tic disorder, $n(\%)$ & 7 (22.6) & $4(23.5)$ \\
\hline Transient tic disorder, $n(\%)$ & $5(16.1)$ & $6(35.3)$ \\
\hline \multicolumn{3}{|l|}{ Comorbidities } \\
\hline Attention deficit hyperactivity disorder, $n(\%)$ & $9(29.0)$ & $6(35.3)$ \\
\hline Oppositional defiant disorder, $n(\%)$ & $2(6.5)$ & $0(0)$ \\
\hline Obsessive compulsive disorder, $n(\%)$ & $3(9.7)$ & $0(0)$ \\
\hline Duration of tic disorders mean (SD), years & $3.4(2.9)$ & $2.3(2.3)$ \\
\hline Dose/day mean (SD), mg & $10.6(5.2)$ (range: $2.5-20.0)$ & $1.9(1.1)$ (range: $0.75-4.5)$ \\
\hline Duration of study medication mean (SD), days & 51.7 (12.6) (range: 14-60) & $46.3(15.8)$ (range: $15-61)$ \\
\hline
\end{tabular}


Table 2 Efficacy of aripiprazole and haloperidol in the treatment of tic disorders

\begin{tabular}{|c|c|c|c|c|c|c|c|c|c|c|}
\hline \multirow[t]{3}{*}{ Outcome measures } & \multicolumn{2}{|c|}{$\begin{array}{l}\text { Aripiprazole group } \\
(n=31)\end{array}$} & \multicolumn{2}{|c|}{$\begin{array}{l}\text { Haloperidol group } \\
(n=17)\end{array}$} & \multicolumn{6}{|c|}{ Statistical value ${ }^{\mathrm{a}}$} \\
\hline & \multirow[t]{2}{*}{ Baseline } & \multirow[t]{2}{*}{8 weeks } & \multirow[t]{2}{*}{ Baseline } & \multirow[t]{2}{*}{8 weeks } & \multicolumn{2}{|c|}{ Group effect } & \multicolumn{2}{|c|}{ Time effect } & \multicolumn{2}{|c|}{$\begin{array}{l}\text { Group } \times \text { time } \\
\text { Interaction effect }\end{array}$} \\
\hline & & & & & $z$ & $p$ & $z$ & $p$ & $z$ & $p$ \\
\hline \multicolumn{11}{|l|}{ YGTSS mean (SD) } \\
\hline Motor tic scores & $17.5(5.3)$ & $8.0(4.4)$ & $20.5(3.1)$ & $8.5(6.7)$ & -1.21 & 0.227 & -8.29 & $<0.001$ & 0.61 & 0.540 \\
\hline Phonic tic scores & $9.0(6.7)$ & $4.5(4.6)$ & $7.1(8.3)$ & $2.4(4.3)$ & 0.99 & 0.320 & -5.59 & $<0.001$ & 1.13 & 0.258 \\
\hline Total tic scores & $26.5(4.9)$ & $12.1(6.4)$ & $27.6(7.3)$ & $10.1(7.5)$ & -0.61 & 0.543 & -9.60 & $<0.001$ & 1.28 & 0.201 \\
\hline \multicolumn{11}{|l|}{ CGI-I, $n(\%)^{\mathrm{b}}$} \\
\hline Very much improved & - & $9(34.6)$ & - & $5(45.5)$ & - & - & - & - & & \\
\hline Much improved & - & $13(50.0)$ & - & $5(45.5)$ & & & & & & \\
\hline Minimally improved & - & $3(16.7)$ & - & $0(0)$ & & & & & & \\
\hline No change & - & $1(3.8)$ & - & $1(9.1)$ & & & & & & \\
\hline Minimally aggravated & - & 0 & - & 0 & & & & & & \\
\hline Much aggravated & - & 0 & - & 0 & & & & & & \\
\hline \multicolumn{11}{|l|}{ CGI-S, $n(\%)$} \\
\hline Normal, not Ill & 0 & $2(7.7)$ & 0 & $1(9.1)$ & -0.94 & 0.35 & -8.83 & $<0.001$ & 0.69 & 0.490 \\
\hline Minimally ill & 0 & $8(30.7)$ & 0 & $6(54.5)$ & & & & & & \\
\hline Mildly ill & 0 & $10(38.5)$ & 0 & $3(27.3)$ & & & & & & \\
\hline Moderately ill & $4(12.9)$ & $3(11.5)$ & $1(20.0)$ & 0 & & & & & & \\
\hline Markedly ill & $12(38.7)$ & $3(11.5)$ & $7(36.9)$ & 0 & & & & & & \\
\hline Severely ill & $15(48.4)$ & 0 & $9(37.5)$ & $1(9.1)$ & & & & & & \\
\hline Extremely severely ill & 0 & 0 & 0 & 0 & & & & & & \\
\hline
\end{tabular}

${ }^{a}$ To examine the group and time effects for each outcome variable, generalized estimation equation (GEE) modeling was adopted, with age, gender, duration of illness, and baseline scores for each outcome variable included as covariates

${ }^{\mathrm{b}}$ Calculating patients who dropped-out

YGTSS yale global tic severity scale, CGI-I clinical global impression-improvement, $C G I-S$ clinical global impression-severity of illness

medication prematurely owing to intolerability. In contrast, all 17 subjects in the haloperidol group experienced unexpected side effects and $6(35.3 \%)$ were not able to continue medication owing to unbearable adverse events. Although frequencies of side effects between two groups during study period were not different $\left(\chi^{2}=2.08, p=0.15\right)$, rates of drug discontinuation were lower in the aripiprazole group relative to the haloperidol group $\left(\chi^{2}=7.17, p=0.007\right)$. The major intolerable side effects included nausea (2 patients), headache ( 2 patients) and sedation (1 patient) in the aripiprazole group, and sedation (4 patients) and headache ( 2 patients) in the haloperidol group.

\section{Extrapyramidal symptom rating scale}

The total ESRS score at study endpoint was higher in the haloperidol than in the aripiprazole group. There were interaction effects between groups and a time effect of the total ESRS score $(Z=-2.17, p=0.03)$. Total ESRS scores did not change significantly in the aripiprazole group between 2 and 4 weeks $(1.1 \pm 1.7$ and $1.1 \pm 1.8$, respectively), but increased significantly in the haloperidol group between 2 and 4 weeks $(1.4 \pm 2.1$ and $2.8 \pm 2.6$, respectively); these interaction effects were statistically significant $(Z=-2.083, p=0.037$ ) (Fig. 2). In addition, the subscale scores for Parkinsonism, akathisia and, dystonia were higher in the haloperidol group at 8 weeks. The Parkinsonism subscale of the ESRS showed an interaction effect between group and time $Z=-2.06, p=0.04)$. No subjects experienced dyskinesia in this study (Table 3 ).

General adverse events

The most common side effects of aripiprazole were hypersomnia (58.1\%), nausea/vomiting (29.0\%), EPS (19.4\%), and headache $(16.1 \%)$, whereas the most common side effects of haloperidol included hypersomnia $(82.4 \%)$, headache (58.8\%), EPS (41.2\%), nausea/vomiting $(23.5 \%)$, gastrointestinal disturbances $(11.8 \%)$, emotional hypersensitivity $(11.8 \%)$, dizziness $(11.8 \%)$, and chest discomfort (11.8\%) (Table 4). Hypersomnia $\left(\chi^{2}=4.17, p=0.04\right)$, EPS $\left(\chi^{2}=7.84, p=0.005\right)$, and headache $\left(\chi^{2}=24.34\right.$, 

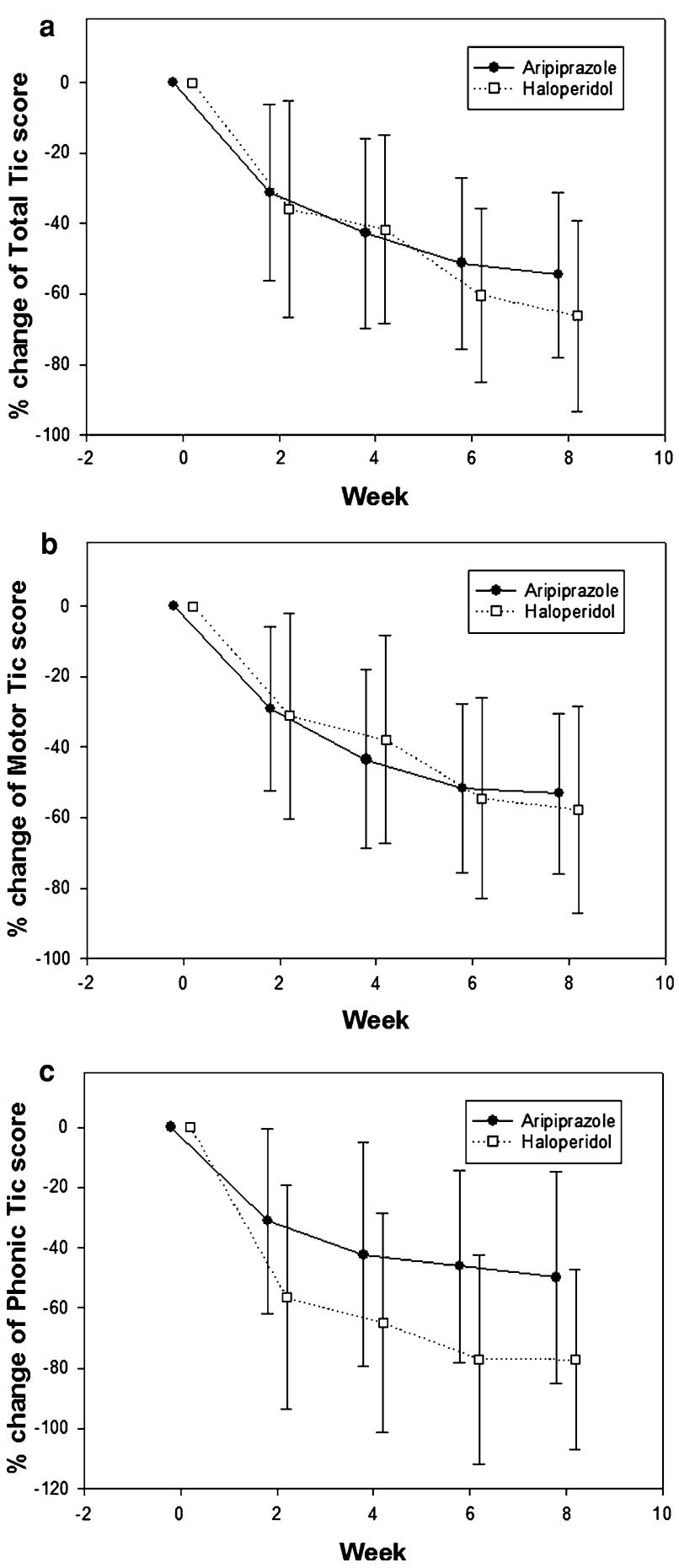

Fig. 1 a Percentage changes in total tic scores over time in the aripiprazole and haloperidol treatment groups. b Percentage changes in motor tic scores over time in the aripiprazole and haloperidol treatment groups. c Percentage changes in phonic tic scores over time in the aripiprazole and haloperidol treatment groups The error bars refer to standard deviation

$p<0.001$ ) were observed less frequently in the aripiprazole group. All laboratory results before, during and after treatment were within normal limits. Any abnormalities in the

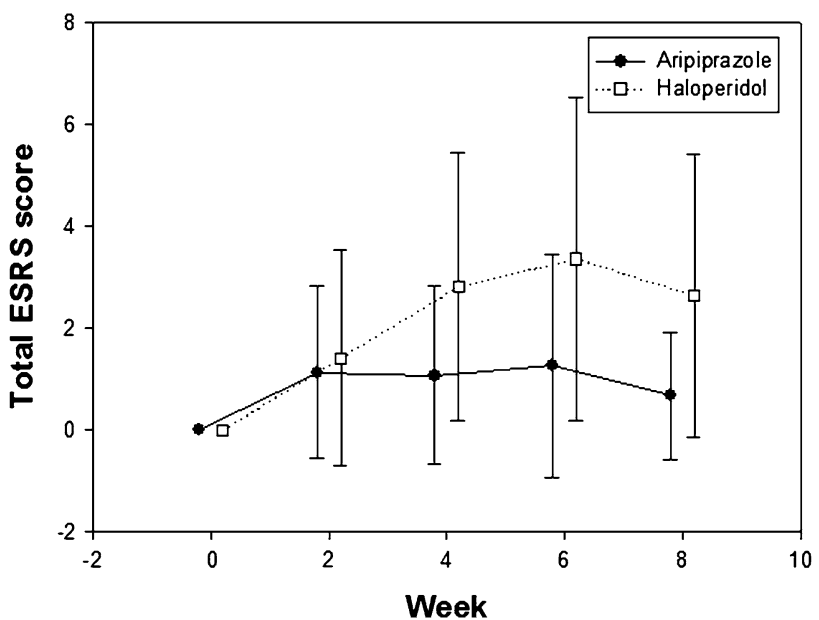

Fig. 2 Changes in ESRS scores over time in the aripiprazole and haloperidol treatment groups. Abbreviations ESRS extrapyramidal symptom rating scale. The error bars refer to standard deviation

results of the ECGs including QTc changes were observed before and after treatment. Between baseline and 8 weeks, the mean body weight of the subjects in the aripiprazole and haloperidol groups increased $0.16 \mathrm{~kg} /$ week and $0.21 \mathrm{~kg} /$ week, respectively, but these increases did not differ between the two groups (Mann-Whitney $U$ test, $Z=0.291$, $p=0.771)$.

\section{Discussion}

To our knowledge, this study is the first to directly compare the efficacy and tolerability of aripiprazole and haloperidol in the treatment of children and adolescents with tic disorders. We found that aripiprazole was as effective as haloperidol in reducing tic symptoms, as well as being better tolerated. The mean dose of aripiprazole used in this study, $10.6 \mathrm{mg} / \mathrm{d}$, was similar to that used in our previous studies in which children and adolescents with tic disorders were treated with aripiprazole [16, 23, 24], and to doses used in previous studies of youths with developmental disabilities [33-35], delusional disorder [36], and bipolar disorders [37]. In contrast, higher doses of aripiprazole have been used to treat children and adolescents with bipolar disorders [38, 39], catatonia [40], and generalized anxiety disorder [41], as well as in psychiatric inpatients [42]. The aripiprazole dose used in this study was lower than that used in adults with Tourette disorder [21, 43-45].

Although various atypical antipsychotics are widely used to treat tic disorders, they had weaker efficacy than typical neuroleptics such as haloperidol and pimozide, which can decrease tic symptoms by more than $60 \%$ [29]. Even the first atypical antipsychotic, clozapine, was not able to sufficiently 
Table 3 Extrapyramidal symptom rating scale scores at study endpoint in the aripiprazole and haloperidol groups

\begin{tabular}{|c|c|c|c|c|c|c|c|c|}
\hline \multirow{3}{*}{$\begin{array}{l}\text { Extrapyramidal symptom rating } \\
\text { scale scores mean (SD) }\end{array}$} & \multirow{3}{*}{$\begin{array}{l}\text { Aripiprazole } \\
\text { group }\end{array}$} & \multirow{3}{*}{$\begin{array}{l}\text { Haloperidol } \\
\text { group }\end{array}$} & \multicolumn{6}{|c|}{ Statistical value $^{\mathrm{a}}$} \\
\hline & & & \multicolumn{2}{|c|}{ Group effect } & \multicolumn{2}{|c|}{ Time effect } & \multicolumn{2}{|c|}{ Group $\times$ time interaction effect } \\
\hline & & & $z$ & $p$ & $z$ & $p$ & $z$ & $p$ \\
\hline Parkinsonism & $0.58(1.06)$ & $1.91(1.92)$ & -0.10 & 0.92 & 2.33 & 0.02 & -2.06 & 0.04 \\
\hline Akathisia & $0.04(0.20)$ & $0.36(0.67)$ & 0.59 & 0.56 & 1.66 & 0.10 & -1.76 & 0.08 \\
\hline Dystonia & $0.04(0.20)$ & $0.36(0.67)$ & -0.67 & 0.50 & -0.05 & 0.96 & -0.44 & 0.66 \\
\hline Dyskinesia & $0.00(0.00)$ & $0.00(0.00)$ & & & & & & \\
\hline Total & $0.68(1.25)$ & $2.64(2.77)$ & -0.00 & 1.00 & 2.17 & 0.03 & -2.17 & 0.03 \\
\hline
\end{tabular}

${ }^{a}$ Group and time effects on the adverse effect outcome variables were evaluated using generalized estimation equation (GEE) modeling, with age, gender, duration of illness, and baseline scores for each outcome variable included as covariates

Table 4 Adverse effects of aripiprazole and haloperidol in the current study

\begin{tabular}{lcc}
\hline & $n(\%)$ & \\
\cline { 2 - 3 } Adverse events & $\begin{array}{l}\text { Aripiprazole } \\
(n=31)\end{array}$ & $\begin{array}{c}\text { Haloperidol } \\
(n=17)\end{array}$ \\
\hline Hypersomnia & $18(58.1)$ & $14(82.3)$ \\
Nausea/vomiting & $9(29.0)$ & $4(23.5)$ \\
Extrapyramidal symptoms & $6(19.4)$ & $7(41.2)$ \\
Headache & $5(16.1)$ & $10(58.8)$ \\
GI disturbances & $2(6.5)$ & $2(11.8)$ \\
Dry mouth & $2(6.5)$ & $2(11.8)$ \\
Emotional hypersensitivity & $1(3.2)$ & $2(11.8)$ \\
Dizziness & $1(3.2)$ & $2(11.8)$ \\
Chest discomfort & $1(3.2)$ & $2(11.8)$ \\
Anorexia & $1(3.2)$ & $2(11.8)$ \\
Nocturia & $1(3.2)$ & $1(5.9)$ \\
Increased appetite & $1(3.2)$ & $1(5.9)$ \\
Insomnia & $1(3.2)$ & $2(11.8)$ \\
Nightmare & $1(3.2)$ & $1(5.9)$ \\
Polydipsia & $1(3.2)$ & 0 \\
Blurred vision & $1(3.2)$ & 0 \\
Joint pain & 0 & $2(11.8)$ \\
Febrile sense & 0 & $1(5.9)$ \\
School refusal & 0 & $1(5.9)$ \\
\hline
\end{tabular}

abate tic symptoms [5]. Although olanzapine showed considerable efficacy, its adverse effects, such as weight gain and sedation, limits its use for tic control $[4,10]$. Uses of quetiapine have been reported in several case reports [12, 46-49] and open-label trials [13, 49] to decrease tic symptoms. However, in two open-label trials testing quetiapine as an anti-tic drug in children and adolescents with Tourette disorder, its efficacy and tolerability were questionable. Risperidone is one of the most widely used and best-studied atypical antipsychotics in the treatment of tic symptoms. Although relatively safe and effective in tic reduction, risperidone diminishes tic symptoms by less than
$36 \%$ [3, 6-9, 50, 51]. A double-blind, randomized trial on the efficacy of ziprasidone in reducing tic symptoms showed that it reduced tic symptoms by $35 \%$, although side effects, most of which were tolerable, developed in more than $80 \%$ of patients [52].

Aripiprazole may be more potent than other atypical antipsychotics, reducing tic symptoms by $40-53 \%$ [23, 24]. Aripiprazole was also found to be effective in treating antipsychotic-resistant patients with Tourette disorder [19, $21]$. In the current study, 15 subjects $(48.4 \%)$ in the aripiprazole group and $3(17.6 \%)$ in the haloperidol group had histories of previous ineffective treatment with antipsychotic medication; nevertheless, the efficacy of aripiprazole was equivalent to that of haloperidol, suggesting that aripiprazole may be a drug of choice for drug-resistant tic patients, although further confirmation is required.

In our previous report, aripiprazole was effective at its initial dose, $5 \mathrm{mg}$, with $62.0 \%$ of the total reduction in Total Tic Score attained within 2 weeks after the start of treatment [24]. Although we found that tic severity in the aripiprazole group diminished almost linearly from 2 to 8 weeks, the reduction during the first 2 weeks, during treatment with the initial dose of $5 \mathrm{mg} / \mathrm{day}$, accounted for $60.0 \%$ of the total reduction in Total Tic Score, observed in this study. This indicates that aripiprazole may be useful in the treatment of children and adolescents with tic disorders, especially those with unbearable or strongly dysfunctional tic symptoms who need prompt symptom improvement.

More than $80 \%$ of youths taking aripiprazole experienced one or more unwanted side effects. This high incidence may have been due to the starting dose of $5 \mathrm{mg}$, which may be too high in children and adolescents with tic disorders. Nineteen subjects $(61.3 \%)$ in the aripiprazole group experienced side effects after their first dose, with the side effects experienced by four patients $(21.1 \%)$ disappearing spontaneously without any management or dose reduction at the next visit. Further clinical studies using lower initial doses of aripiprazole are required to confirm this possibility. 
In addition to the higher dropout rate seen in the haloperidol group, the rate of EPS during the 4 weeks after starting treatment was higher in the haloperidol than in the aripiprazole group. This may be associated with differences in receptor profiles of the two drugs. Haloperidol has a strong antagonistic affinity to dopamine 2 receptors in the nigrostriatal dopamine pathway, causing EPS [53], whereas aripiprazole has partial agonistic activity at the postsynaptic dopamine 2 receptors, reducing EPS development [14].

Aripiprazole may be a more ideal anti-tic drug owing to its unique pharmacodynamic profile, including both antagonistic and agonistic dopamine activities, depending on the environment of the local dopamine system $[14,54]$. This activity is strongly associated with the pathological mechanism of tic disorders. Dopamine receptor hypersensitivity may be an underlying pathology of tic disorders [15]. Although several studies have confirmed the supersensitivity of the dopamine system in tic disorders, these studies did not consider the anti-dopaminergic drug effects [55-57], and several neuroimaging studies assessing influences of drugs on the dopamine system have yielded conflicting results [58-60]. Significantly, pergolide, a typical dopamine agonist, reduced tic symptoms in two previous randomized, controlled clinical studies [61, 62]. Thus, an imbalance in dopamine systems may be a pivotal cause of tic disorders. The stabilizing action of aripiprazole in an environment of unbalanced dopamine status, therefore, as in tic-affected brain areas, may be more ideal in abating tic symptoms.

Apart from acting as a partial dopamine agonist, aripiprazole has serotonin $2 \mathrm{~A}$ antagonistic properties, which may also facilitate its ability to stabilize the dopamine system by increasing dopamine release [63]. The serotonin $2 \mathrm{~A}$ receptor has been associated with tic symptoms, both in animals [64] and humans [65]. In addition, the partial agonistic actions of aripiprazole at the serotonin 1A receptor might improve tic symptoms by decreasing anxiety [66], which occurs frequently in patients with tic disorders and has been associated with tic aggravation [1]. Moreover, the partial agonistic activities of aripiprazole on the dopamine 3 and 4 receptors may be correlated with the effects of this drug on tic disorders, as shown both clinically $[61,62]$ and genetically [67-69].

Although our findings indicate that aripiprazole has equivalent efficacy but higher tolerability than haloperidol in children and adolescents with tic disorders, our study had several limitations, including the small sample size, openlabel approach, and short-term nature of the study. Thus, we cannot confirm the tolerability and long-term efficacy of aripiprazole in these patients. In addition, because the patients chose aripiprazole or haloperidol, it could result in differences such as age and baseline scores among the groups of patients. Double-blind, placebo-controlled, and randomized trials should be performed to overcome these limitations and determine whether aripiprazole improves tic symptoms or if our findings reflect the natural progression of tic disorders.

\section{Conclusions}

Our findings indicate that aripiprazole may be effective and tolerable in the treatment of children and adolescents with tic disorders. Additional controlled studies are needed to determine the efficacy and tolerability of aripiprazole in patients with tic disorders.

Conflict of interest We have no disclosures. We report no financial affiliation or other relationship relevant to the subject of this article.

Open Access This article is distributed under the terms of the Creative Commons Attribution Noncommercial License which permits any noncommercial use, distribution, and reproduction in any medium, provided the original author(s) and source are credited.

\section{References}

1. Rampello L, Alvano A, Battaglia G, Bruno V, Raffaele R, Nicoletti F (2006) Tic disorders: from pathophysiology to treatment. J Neurol 253:1-15

2. Sallee FR, Nesbitt L, Jackson C, Sine L, Sethuraman G (1997) Relative efficacy of haloperidol and pimozide in children and adolescents with Tourette's disorder. Am J Psychiatry 154: 1057-1062

3. Bruun RD, Budman CL (1996) Risperidone as a treatment for Tourette's syndrome. J Clin Psychiatry 57:29-31

4. Budman CL, Gayer A, Lesser M, Shi Q, Bruun RD (2001) An open-label study of the treatment efficacy of olanzapine for Tourette's disorder. J Clin Psychiatry 62:290-294

5. Caine ED, Polinsky RJ, Kartzinel R, Ebert MH (1979) The trial use of clozapine for abnormal involuntary movement disorders. Am J Psychiatry 136:317-320

6. Gaffney GR, Perry PJ, Lund BC, Bever-Stille KA, Arndt S, Kuperman S (2002) Risperidone versus clonidine in the treatment of children and adolescents with Tourette's syndrome. J Am Acad Child Adoles Psychiatry 41:330-336

7. Gilbert DL, Batterson JR, Sethuraman G, Sallee FR (2004) Tic reduction with risperidone versus pimozide in a randomized, double-blind, crossover trial. J Am Acad Child Adolesc Psychiatry 43:206-214

8. Kim BN, Lee CB, Hwang JW, Shin MS, Cho SC (2005) Effectiveness and safety of risperidone for children and adolescents with chronic tic or tourette disorders in Korea. J Child Adolesc Psychopharmcol 15:318-324

9. Scahill L, Leckman JF, Schultz RT, Katsovich L, Peterson BS (2003) A placebo-controlled trial of risperidone in Tourette syndrome. Neurology 60:1130-1135

10. Stamenkovic M, Schindler SD, Aschauer HN, De Zwaan M, Willinger U, Resinger E, Kasper S (2000) Effective open-label treatment of tourette's disorder with olanzapine. Int Clin Psychopharmcol 15:23-28

11. Stephens RJ, Basse C, Sandor P (2004) Olanzapine in the treatment of aggression and tics in children with Tourette's 
syndrome - a pilot study. J Child Adolesc Psychopharmcol 14: 255-266

12. Barzman D, Gernert B, Delbello M (2004) Quetiapine for chronic motor tic disorder. Am J Psychiatry 161:1307

13. Copur M, Arpaci B, Demir T, Narin H (2007) Clinical effectiveness of quetiapine in children and adolescents with Tourette's syndrome: a retrospective case-note survey. Clin drug Invest 27:123-130

14. DeLeon A, Patel NC, Crismon ML (2004) Aripiprazole: a comprehensive review of its pharmacology, clinical efficacy and tolerability. Clin Ther 26:649-666

15. Leckman JF (2002) Tourette's syndrome. Lancet 360:1577-1586

16. Budman C, Coffey BJ, Shechter R, Schrock M, Wieland N, Spirgel A, Simon E (2008) Aripiprazole in children and adolescents with Tourette disorder with and without explosive outbursts. J Child Adolesc Psychopharmacol 18:509-815

17. Davies L, Stern JS, Agrawal N, Robertson MM (2006) A case series of patients with Tourette's syndrome in the United Kingdom treated with aripiprazole. Hum Psychopharmcol 21:447-453

18. Kawohl W, Schneider F, Vernaleken I, Neuner I (2009) Aripiprazole in the pharmacotherapy of Gilles de la Tourette syndrome in adult patients. World J Biol Psychiatry 10:827-831

19. Lyon GJ, Samar S, Jummani R, Hirsch S, Spirgel A, Goldman R, Coffey BJ (2009) Aripiprazole in children and adolescents with Tourette's disorder: an open-label safety and tolerability study. J Child Adolesc Psychopharmacol 19:623-633

20. Murphy TK, Mutch PJ, Reid JM, Edge PJ, Storch EA, Bengtson M, Yang M (2009) Open label aripiprazole in the treatment of youth with tic disorders. J Child Adolesc Psychopharmacol 19:441-447

21. Padala PR, Qadri SF, Madaan V (2005) Aripiprazole for the treatment of Tourette's disorder. Prim Care Companion J Clin Psychiatry 7:296-299

22. Seo WS, Sung HM, Sea HS, Bai DS (2008) Aripiprazole treatment of children and adolescents with Tourette disorder or chronic tic disorder. J Child Adolesc Psychopharmacol 18:197-205

23. Yoo HK, Choi SH, Park S, Wang HR, Hong JP, Kim CY (2007) An open-label study of the efficacy and tolerability of aripiprazole for children and adolescents with tic disorders. J Clin Psychiatry 68:1088-1093

24. Yoo HK, Kim JY, Kim CY (2006) A pilot study of aripiprazole in children and adolescents with Tourette's disorder. J Child Adolesc Psychopharmcol 16:505-506

25. Kim YS, Cheon KA, Kim BN, Chang SA, Yoo HJ, Kim JW, Cho SC, Seo DH, Bae MO, So YK, Noh JS, Koh YJ, McBurnett K, Leventhal B (2004) The reliability and validity of Kiddie-Schedule for Affective Disorders and Schizophrenia-Present and Lifetime Version-Korean version (K-SADS-PL-K). Yonsei Med J 45:81-89

26. Chung S, Lee J, Yoo T, Koo YJ, Jeon S, Kim B, Hong K (1998) Development of the Korean form of Yale Global Tic Severity Scale: a validity and reliability study. J Korean Neuropsychiatr Assoc 37:942-951

27. Leckman JF, Riddle MA, Hardin MT, Ort SI, Swartz KL, Stevenson J, Cohen DJ (1989) The Yale Global Tic Severity Scale: initial testing of a clinician-rated scale of tic severity. J Am Acad Child Adolesc Psychiatry 28:566-573

28. Park KS, Yoon JR, Park HJ, Park HJ, Kwon JW (1986) Development of the Korean Educational Development Institute Wechsler Intelligence Scale for Children-Revised (KEDI-WISC$\mathrm{R})$, individual intelligence test for Korean children. Korean Educational Development Institute, Seoul

29. Shapiro E, Shapiro AK, Fulop G, Hubbard M, Mandeli J, Nordlie J, Phillips RA (1989) Controlled study of haloperidol, pimozide and placebo for the treatment of Gilles de la Tourette's syndrome. Arch Gen Psychiatry 46:722-730

30. Conners CK, Barkley RA (1985) Rating scales and checklists for child psychopharmacology. Psychopharmcol Bull 21:809-843

31. Guy W (1976) ECDEU assessment manual for psychopharmacology. US Dept Health, Education, and Welfare publication, Rockville

32. Chouinard G, Margolese HC (2005) Manual for the extrapyramidal symptom rating scale (ESRS). Schizophr Res 76:247-265

33. Barzman DH, DelBello MP, Kowatch RA, Gernert B, Fleck DE, Pathak S, Rappaport K, Delgado SV, Campbell P, Strakowski SM (2004) The effectiveness and tolerability of aripiprazole for pediatric bipolar disorders: a retrospective chart review. J Child Adolesc Psychopharmacol 14:593-600

34. Stigler KA, Posey DJ, McDougle CJ (2004) Aripiprazole for maladaptive behavior in pervasive developmental disorders. J Child Adolesc Psychopharmacol 14:455-463

35. Valicenti-McDermott MR, Demb H (2006) Clinical effects and adverse reactions of off-label use of aripiprazole in children and adolescents with developmental disabilities. J Child Adolesc Psychopharmacol 16:549-560

36. Shastri M, Alla L, Sabaratnam M (2006) Aripiprazole use in individuals with intellectual disability and psychotic or behavioural disorders: a case series. J Psychopharmacol 20:863-867

37. Biederman J, Mick E, Spencer T, Doyle R, Joshi G, Hammerness P, Kotarski M, Aleardi M, Wozniak J (2007) An open-label trial of aripiprazole monotherapy in children and adolescents with bipolar disorder. CNS spectr 12:683-689

38. Biederman J, McDonnell MA, Wozniak J, Spencer T, Aleardi M, Falzone R, Mick E (2005) Aripiprazole in the treatment of pediatric bipolar disorder: a systematic chart review. CNS Spectr 10:141-148

39. Durkin JP (2004) Aripiprazole in the treatment of bipolar disorder in children and adolescents. J Child Adolesc Psychopharmacol 14:505-506

40. Strawn JR, Delgado SV (2007) Successful treatment of catatonia with aripiprazole in an adolescent with psychosis. J Child Adolesc Psychopharmacol 17:733-736

41. Menza MA, Dobkin RD, Marin H (2007) An open-label trial of aripiprazole augmentation for treatment-resistant generalized anxiety disorder. J Clin Psychopharmacol 27:207-210

42. Gibson AP, Crismon ML, Mican LM, Fischer C (2007) Effectiveness and tolerability of aripiprazole in child and adolescent inpatients: a retrospective evaluation. Int Clin Psychopharmacol 22:101-105

43. Bubl E, Perlov E, Tebartz Van Elst L (2006) Aripiprazole in patients with Tourette syndrome. World J Biol Psychiatry $7: 123-125$

44. Constant EL, Borras L, Seghers A (2006) Aripiprazole is effective in the treatment of Tourette's disorder. Int J Neuropsychopharmacol/Off Sci J Collegium Internationale Neuropsychopharmacologicum (CINP) 9L:773-774

45. Kastrup A, Schlotter W, Plewnia C, Bartels M (2005) Treatment of tics in tourette syndrome with aripiprazole. J Clin Psychopharmacol 25:94-96

46. Chan-Ob T, Kuntawongse N, Boonyanaruthee V (2001) Quetiapine for tic disorder: a case report. J Medl Assoc Thailand = Chotmaihet Thangphaet 84:1624-1628

47. Little AE, Augustin SG, Kissack JC (2006) Quetiapine in the treatment of tic disorder. Ann Pharmacother 40:1472

48. Parraga HC, Parraga MI, Woodward RL, Fenning PA (2001) Quetiapine treatment of children with Tourette's syndrome: report of two cases. J Child Adolesc Psychopharmacol 11:187-191

49. Mukaddes NM, Abali O (2003) Quetiapine treatment of children and adolescents with Tourette's disorder. J Child Adolesc Psychopharmacol 13:295-299 
50. Dion Y, Annable L, Sandor P, Chouinard G (2002) Risperidone in the treatment of tourette syndrome: a double-blind, placebocontrolled trial. J Clin Psychopharmacol 22:31-39

51. Lombroso PJ, Scahill L, King RA, Lynch KA, Chappell PB, Peterson BS, McDougle CJ, Leckman JF (1995) Risperidone treatment of children and adolescents with chronic tic disorders: a preliminary report. J Am Acad Child Adolesc Psychiatry 34:1147-1152

52. Sallee FR, Kurlan R, Goetz CG, Singer H, Scahill L, Law G, Dittman VM, Chappell PB (2000) Ziprasidone treatment of children and adolescents with Tourette's syndrome: a pilot study. J Am Acad Child Adolesc Psychiatry 39:292-299

53. Niemegeers CJ, Laduron PM (1976) Pharmacology and biochemistry of haloperidol. Proc R Soc Med 69(Suppl 1):3-8

54. Lawler CP, Prioleau C, Lewis MM, Mak C, Jiang D, Schetz JA, Gonzalez AM, Sibley DR, Mailman RB (1999) Interactions of the novel antipsychotic aripiprazole (OPC-14597) with dopamine and serotonin receptor subtypes. Neuropsychopharmacol 20: 612-627

55. Malison RT, McDougle CJ, van Dyck CH, Scahill L, Baldwin RM, Seibyl JP, Price LH, Leckman JF, Innis RB (1995) [123I)beta-CIT SPECT imaging of striatal dopamine transporter binding in Tourette's disorder. Am J Psychiatry 152:1359-1361

56. Muller-Vahl KR, Berding G, Brucke T, Kolbe H, Meyer GJ, Hundeshagen H, Dengler R, Knapp WH, Emrich HM (2000) Dopamine transporter binding in Gilles de la Tourette syndrome. J Neurol 247:514-520

57. Singer HS, Hahn IH, Moran TH (1991) Abnormal dopamine uptake sites in postmortem striatum from patients with Tourette's syndrome. Ann Neurol 30:558-562

58. Lampreave JL, Molina V, Mardomingo MJ, Bittini A, Dominguez P, Almoguera I, Rubia FJ, Carreras JL (1998) Technetium$99 \mathrm{~m}$-HMPAO in Tourette's syndrome on neuroleptic therapy and after withdrawal. J Nucl Med 39:624-628

59. Muller-Vahl KR, Berding G, Kolbe H, Meyer GJ, Hundeshagen H, Dengler R, Knapp WH, Emrich HM (2000) Dopamine D2 receptor imaging in Gilles de la Tourette syndrome. Acta Neurol Scand 101:165-171
60. Turjanski N, Sawle GV, Playford ED, Weeks R, Lammerstma AA, Lees AJ, Brooks DJ (1994) PET studies of the presynaptic and postsynaptic dopaminergic system in Tourette's syndrome. J Neurol Neurosurg Psychiatry 57:688-692

61. Gilbert DL, Dure L, Sethuraman G, Raab D, Lane J, Sallee FR (2003) Tic reduction with pergolide in a randomized controlled trial in children. Neurology 60:606-611

62. Gilbert DL, Sethuraman G, Sine L, Peters S, Sallee FR (2000) Tourette's syndrome improvement with pergolide in a randomized, double-blind, crossover trial. Neurology 54:1310-1315

63. Stahl SM (2001) Dopamine system stabilizers, aripiprazole, and the next generation of antipsychotics, part 2: illustrating their mechanism of action. J Clin Psychiatry 62:923-924

64. Hayslett RL, Tizabi Y (2005) Effects of donepezil, nicotine and haloperidol on the central serotonergic system in mice: implications for Tourette's syndrome. Pharmacol Biochem Behav 81:879-886

65. Rojas-Corrales MO, Gibert-Rahola J, Mico JA (2007) Role of atypical opiates in OCD Experimental approach through the study of 5-HT(2A/C) receptor-mediated behavior. Psychopharmacol (Berl) 190:221-231

66. Millan MJ (2003) The neurobiology and control of anxious states. Prog Neurobiol 70:83-244

67. Cruz C, Camarena B, King N, Paez F, Sidenberg D, de la Fuente JR, Nicolini H (1997) Increased prevalence of the seven-repeat variant of the dopamine D4 receptor gene in patients with obsessive-compulsive disorder with tics. Neurosci Lett 231:1-4

68. Diaz-Anzaldua A, Joober R, Riviere JB, Dion Y, Lesperance P, Richer F, Chouinard S, Rouleau GA (2004) Tourette syndrome and dopaminergic genes: a family-based association study in the French Canadian founder population. Mol Psychiatry 9:272-277

69. Grice DE, Leckman JF, Pauls DL, Kurlan R, Kidd KK, Pakstis AJ, Chang FM, Buxbaum JD, Cohen DJ, Gelernter J (1996) Linkage disequilibrium between an allele at the dopamine D4 receptor locus and Tourette syndrome, by the transmission-disequilibrium test. Am J Hum Genet 59:644-652 